\title{
A POLITIZAÇÃO DO MONSTRO
}

Angélique Christaki

Angélique Christaki Universidade Paris VII Diderot, Paris, França.
RESUMO: As Erínias tinham por função despertar o ódio e a sideração. A politização das Erínias em As Eumênides, de Ésquilo, e sua transformação em Benevolentes seres de fala participam da elaboração na poética do discurso trágico de uma palavra que subjetiva a culpa e o ódio.

Palavras-chave: Erínias, ódio, sideração, política, discurso trágico, língua.

ABSTRACT: The monster's politicization. The role of the Erinyes was to rouse fury and sideration. The politicization of the Erinyes in The Eumenides of Aeschylus and their change into benevolent beings of speech participate in the creation of the poetics of tragic discourse of a word which subjectivities guilty and hatred.

Keywords: Erinyes, hatred, sideration, politics, tragic discourse, language.

DOI - http://dx.doi.org/10.1590/S1516-14982016002007 


\section{O PESADELO DA ALMA}

O presente artigo iniciará uma discussão sobre a transformação da figura monstruosa das Erínias em uma figura benevolente, guardiã da cidade de Atenas. As Erínias são divindades ctonianas de vingança. Segundo algumas fontes, elas são atópicas e sem formas. Segundo outras fontes míticas e poéticas, elas têm uma aparência monstruosa, se apresentam como monstros hediondos e assustadores, têm cabelos de serpentes e olhos sangrentos - "O canto delas é sem lira" (ESCHYLE, 2002), remete a uma voz pura que exige o assassinato como vingança. "Elas secam os mortais de terror, é o pesadelo da alma” (idem), diz Ésquilo sendo o porta-voz de todos.

As Erínias são guardiãs da lei não escrita. Elas vão socorrer os mortos assassinados e exigem dos assassinos o pagamento de uma dívida de sangue implacável: é crime por crime. Perseguem os criminosos, mas não todos. $O$ "pesadelo daalma" nãoassombra qualquerum. AErínias perseguem precisamente aqueles que cometeram o crime maior: o parricídio. Segundo Homero (1973), elas perseguem também aqueles que fazem verter o sangue dos errantes, dos viajantes, dos mendigos e estrangeiros.

Percebamos então que as Erínias despertam para "secar de temor" aquele que terá cometido um parricídio, aquele que terá violentamente desfeito o laço mais natural entre os pais e a criança, ou aquele que não terá reconhecido e respeitado a alteridade mais frágil do outro, a falta mais íntima como alteridade: a pobreza do mendigo, a falha de permanência ou da razão do errante, a curiosidade do viajante, a barbaridade íntima do estrangeiro.

Lembremos, além disso, que as Erínias são divindades temidas e odiadas pelos homens e pelos deuses. Elas despertam o ódio e o temor nos homens e não aceitam nem oferendas, nem sacrifícios da parte dos mortais. Como conciliá-los? Como despertar a benevolência em monstros como esses?

Vamos partir, assim, da hipótese de que a transformação das Erínias em Eumênides se baseia no princípio da inversão do medo em ódio reconhecido e subjetivado. O ódio, diz Georges Guggenheim citado por Jacques Hassoun (HASSOUN, 1998), é um termo sem nuances. E quando esse termo se impõe ao sujeito, ele apaga toda e qualquer palavra da língua.

Assim, quando o ódio se impõe, o pensamento se fixa e o sujeito encontra-se capturado melancolicamente em sua própria violência odiosa e destrutiva.

"O sujeito odioso, vítima de seu próprio ódio, é aquele que, devorado pelo horror que o outro faz nascer nele, se empenha em destruir essa suposta causa de sua indignidade. Fanático por essa ideia obsessora, ele não para de suscitar e em seguida de rastrear esse objeto obscuro da raiva desesperada para melhor destruí-lo, para melhor destruir-se também." (HASSOUN, 1998) 
Se o ódio paralisa o pensamento, a questão é a seguinte: o que é que pode devolver a força à palavra livre que agoniza? Como converter o ódio — que fixa a língua e que visa a destruição de toda e qualquer alteridade - em possibilidade de dizer?

\section{UMA LONGA LINHAGEM DE ASSASSINOS PERANTE A LEI}

Ora, a possibilidade de dizer ressoa com a possibilidade de confiar e de viver junto. Essas questões são eminetemente políticas e encontram sua elaboração mais potente no gênero trágico, que tece a política com a trama poética do dizer. Como viver junto e como confiar na palavra se, como indica Freud, somos todos oriundos de uma longa linhagem de assassinos? (FREUD apud HASSOUM, 1998, p.54).

A respeito disso, a linhagem dos Atreides constitui uma das mais monstruosas em matéria de assassinato, de incesto e de canibalismo. Teria sido preciso cinco gerações de crime desde Tântalo até Orestes para que a subjetivação de um ódio ancestral e a emergência de uma culpa se substantificassem por meio do despertar das Erínias, em um pesadelo que torturará a alma de Orestes. Esse pesadelo será apresentado porÉsquilo perante a lei da cidade, diante do tribunal supremo de Atenas: o Areópago. Todavia, para desdobrar o crime de Orestes, é preciso voltar à sua fonte.

\section{Anamnese dos Atreides}

Tudo começa com Pélope, pai de Atreu. Pélope é morto por seu pai Tântalo, eé, em seguida, comido pelos deuses em um banquete que Tântalo oferece em seu palácio. Mas Zeus traz Pélope de voltaà vida eeste se torna então rei de Élide. Dois gêmeos, Atreu e Tiestes, nascem do casamento de Pélope com Hipodâmia, mas eles se veem banidos pelo pai após o mesmo ter matado o irmão mais novo deles. Os gêmeos se refugiam em Micenas. Atreu torna-se rei e se casa com Aérope.

Contudo, Tiestes dorme com Aérope, mulher de seu irmão Atreu, e quando Atreu descobre o incesto massacra os filhos de Tiestes e os serve como jantar em um banquete (o banquete de Tiestes). Assim, Tiestes come os próprios filhos sem sabere, como fica sem descendentes homens, viola a filha Pelópia, que Ihe dá um filho, Egisto, a fim de que este possa vingar seu pai Tiestes nas gerações seguintes.

Egisto assassina Atreu, mas Agamenon, filho de Atreu, apodera-se do trono (que, entretanto, passara pelas mãos de Tiestes). Agamenon se casa com Clitemnestra e eles têm três crianças. Uma de suas filhas, Ifigênia, será morta, sacrificada aos deuses pelo próprio pai Agamenon para que a frota grega se expanda e possa assim partir para a guerra de Troia. 
Agamenon, em seu retorno da guerra de Troia, éassassinado por Clitemnestra e Egisto - que a essa altura já tinham se tornado amantes. Desse modo, Clitemnestra se vinga do assassinato de sua filha Ifigênia por Agamenon.

Enfim, Orestes, para vingar o assassinato do pai, cometido pela mãe Clitemnestra juntamente com o amante, mata os dois. Na versão de Ésquilo, Orestes é em seguida assediado pelas Erínias, que o perseguem até Atenas. Orestes se encontra diante do Areópago para se pronunciar e se explicar a respeito de seu crime perante a lei da cidade de Atenas.

Partemos dofato de quea perpetuação cega dos crimes dos Atreides encontra sua fonte no incesto, no assassinato e no canibalismo. Assim, uma culpa muda, uma falta de palavra se perpetua de geração em geração, como o protótipo de enquistamento de um ódio que implica um entrave a qualquer elaboração psíquica em relação a esse real.

Ora, o assassinato e o incesto, desde sempre, se realizaram no âmbito dos mitos. Mas as Erínias que assediam Orestes encontram-se, pela primeira vez, no centro de um processo que lhes dá acesso à palavra. A subjetivação dessa culpa passa pela politização do monstro mítico, por essa operação que acontece no coração da cidade e no tribunal do Areópago.

O interdito do assassinato e do incesto introduzido neste tribunal constitui o objeto de um debate que dialetiza ao mesmo tempo a lei da cidade e a lei não escrita representada pelas Erínias. Esse duplo interdito se torna assim promotor do direito penal e o organizador de um laço social pacificado.

\section{UMA INTERPRETAÇÃO POLÍTICA DO MONSTRO: AS EUMÊNIDES}

Mas para apreender as problemáticas que na fala trágica produzem a transformação das Erínias em Eumênides, é preciso levar em conta o contexto político e social no qual Ésquilo escreve sua trilogia. Esse contexto está impregnado da destituição política do Areópago enquanto acontecimento que confere ao mito sua interpretação política.

Poresse prisma, a mudança de denominação do monstro na língua éinseparável dos acontecimentos na vida política daépoca, considerando quea concepção mítica do crime de Orestes se elabora em reflexão política ejurídica, adquirindo uma nova significação enraizada no acontecimento do regime democrático no mundo clássico.

Mais especificamente, por volta de 461, Ephialtes ${ }^{1}$ e o seu grupo político convenceram a Assembleia do povo a votar uma lei destituindo o poder político do Areópago. O Areópago era o antigo conselho aristocrático no qual participavam

\footnotetext{
${ }^{1}$ Ephialtes, o adversário de Kímon e o antecessor de Péricles, significa "pesadelo".
} 
os homens mais influentes de Atenas, local onde eram tomadas as decisões em matéria de política externa e interna. A destituição política do Areópago é um ato político maior. Por um lado, ele implica o enfraquecimento político do ramo aristocrático em benefício da Assembleia do povo; por outro, através desse ato, opera-se a separação das instâncias jurídicas das instâncias políticas do Estado e demarca-se a democracia sob a forma mais desenvolvida naquele momento. Essa nova representação, essa nova significação para o homem é inseparável do "sentimento de uma vulnerabilidade um tanto particular. Ao vasto espaço da ação respondia a experiência da extrema dificuldade de tomada de decisão; em respostaàliberdadederemeter-sesomentea simesmotemosa plenaconsciência do sofrimento humano" (MEIER, 1980).

Nasequência desseato político absolutamente decisivo para a sorte da democracia em Atenas, alcança-se em sua plenitude a representação do cidadão livre. Plutarco escreve: "Ephialtes tinha estendido o copo da liberdade aos cidadãos tão cheio que ter-se-iam dele se embriagado" (PLUTARQUE, 2012).

Essa reforma provocara um drama na cidade: Ephialtes fora assassinado enquanto que a ameaça de uma guerra civil pairava sobre Atenas. Assassinato, guerra civil e medo de uma dissolução da democracia compõem o debate mais atual da sociedade ateniense da época. Tal é o contexto político e social quando Ésquilo leva Orestes perseguido pelas Erínias ao Areópago.

\section{O PREÇO DA PALAVRA LIVRE}

Após a destituição política do Areópago, a política se torna assunto do cidadão. A nova realidade dota o cidadão de um poder político sem precedentes, ele está agora sozinho para decidir sobre seus atos, suas falas e o bem da cidade. Assim, alcança-se plenamente o estatuto da liberdade da palavra na cidade, uma liberdade que se desenha tanto como ideal quanto como responsabilidade.

Mas esse ideal de liberdade não carrega menos ódio ou fascinação. A idealização e a fascinação veiculam o ódio pelos lugares segmentados da cidade, lugares de conspiração, ali onde se preparam o assassinato, a traição, a exclusão e a transgressão da lei.

Ódio e fascinação, por quê? O cidadão descobre-se livre, e essa liberdade encontra como limite a insustentável vulnerabilidade despertada pelo ódio de umafalta íntima. Oterrível encontro comessafalta despertaesse real monstruoso, que os Anciãos haviam nomeado como Erínias. Em torno desse real, a fala trágica acompanha o impensável do ato, fazendo advir a responsabilidade do sujeito comoúnico remédiofaceàs consequências monstruosas doatoletal eincestuoso desde sempre realizado na língua. 
Sair da sideração que implica o encontro com o real da vulnerabilidade íntima foi o caminho do surgimento da responsabilidade cidadã. Essa responsabilidade não é dada de saída, ela se elabora plenamente no discurso trágico, uma modalidade de fala que evolui ao lado do debate democrático, da dialética e da argumentação.

Essas disposições de discursos podem, além de tudo, ser consideradas como saídas possíveis do lugar de risco de mortificação da língua, elas levam em conta esse risco e também a falta de promessa inerente à fala diante da descoberta intempestiva da insustentável fragilidade do ser falante. Sem promessas, a fala trágica deixa ao homem somente a liberdade última da responsabilidade de um dizer justo. Mas para dizer, para que a fala tenha um sentido, para que a fragilidade íntima possa se transformar em responsabilidade do dizer, é preciso que o simbólico ganhe raiz, uma raiz que apreende sua fonte na possibilidade de poder confiar para dizer.

\section{A CONFIANÇA COMO RAIZ DO SIMBÓLICO}

Confiar rima com a possibilidade de ser ativo, com a possibilidade de um dizer. Ao longo desse dizer, os enquistamentos de ódio que fixam a língua e o pensamento podem se desdobrar. Resistir a essa fossilização é atravessar os campos mortificados do pensamento, travessias que abrem em direção à simbolização deste afeto primário que é o ódio. De tais travessias a palavra se enraíza em uma confiança suscetível de fazer laço, um laço que tece a língua ao corpo, um laço que permite que o corpo seja afetado. Um laço assim é também um laço político, pois ele está na origem da confiança na palavra.

Um corpo afetado é um corpo em dívida; pagar parte de sua dívida, ali onde o ódio despertaria a culpa, dependeria da capacidade de elaboração dos afetos que mesmo quando enganosos dão crédito à fala. Ora, quando a subjetivação do ódio e o despertar da culpa, sob a forma de Erínias, se elaboram em dívida de fala, e isso diante da lei, como é o caso de Orestes, o ser falante se encontra envolvido em uma operação vital para a palavra por ser esta operação desalienante. Uma operação como essa ocorrera da maneira mais desenvolvida na tragédia antiga, que é "de todos os gêneros literários que surgem (aquele que é) então o mais estritamente ligado à expansão de Atenas e de sua democracia" (ROMILLY, 1992, p.189).

Quando os atenienses iam ao teatro para assistir a uma representação, iam para ver histórias conhecidas e para assistir à elaboração inédita no discurso trágico de um dizer inaudito. Os Anciãos sabiam por antecipação o desfecho do drama, por tudo já ter se realizado no mito ou na cidade. Mas a surpresa premanece nos interstícios do discurso trágico, na liberdade poética do dizer, 
como via real para a de-sideração da língua e para a desalienação da palavra. Essa liberdade toda trágica é tecida em volta de um real monstruoso, que a trama poética da fala trágica borda sem que, no entanto, haja a menor esperança de que o homem possa se desfazer dela definitivamente.

As travessias se fazem na língua e com a palavra - e é isso que apaixonava o público ateniense de então. As pessoas iam ao teatro para assistir à surpresa poética desvendada pela arte do poeta nas ressonâncias do dizer. O que interessava aos espectadores atenienses era o que iria se realizar na língua, pois é na poética de um dizer trágico que mora a decisão do sujeito face à sua própria vulnerabilidade, face à sua própria monstruosidade, uma decisão, uma desalienação como consequência do ato.

É, além disso, nesse nível que se exerce e se elabora a liberdade do sujeito como decisão do desejo na palavra, na fala, uma decisão, uma desalienação que não se dá no plano da razão, mas que ressoa na língua que interrompe e contesta toda a racionalidade e toda a moralidade.

\section{BENEVOLENTES: AS INTERLOCUTORAS DO CIDADÃO}

Em As Eumênides, os deuses são divididos, e entre os poderes divinos não se trata mais apenas da questão de Orestes e seu matricídio. Na verdade, as posições de duas partes divinas, entre os deuses do Olimpo e as Erínias, estão tão difíceis, extremas, que a questão que emerge no tribunal do Aerópago é: “O que é verdadeiramente justo?" A problemática que se desdobra é tanto teológica quanto política e coloca questões acerca do conteúdo da lei e da alteridade. Ora, é precisamentea reflexão sobre a democracia que veicula essas questões em AsEumênides.

Paralelamente, o discurso trágico coloca as mesmas interrogações, fazendo da trama poética da palavra um lugar onde pode se desenvolver uma forma política do dizer que não implica nenhuma decisão a não ser aquela do desejo como responsabilidade de um dizer.

As Erínias obtêm o direito de cidadania no momento preciso em que a responsabilidade política e jurídica do cidadão são liberados. O monstro odioso e incompreensível se desloca para o coração da cidade, ele se torna interlocutor do cidadão. As Erínias se transformam em Benevolentes, guardiãs da cidade de Atenas, na medida em que a língua trágica considera o ódio ignorado, tal é a falta de palavra que havia até aqui sustentado a perpetuação cega do crime.

A passagem das Erínias a Benevolentes intervém como uma marca de confiança que deu novamente raizà palavra após o inaudito e o indizível terem sido acolhidos na cidade diante da lei.

Pela primeira vez esses monstros aterrorizadores e sanguinários falam, argumentam enegociam poeticamente com o cidadão e com a lei da cidade, introdu- 
zem uma nova tópica subjetiva. O monstroestá na cidadee desdeentãoécom ele que o combate se torna palavra, negociação com um destino incestuoso e letal.

A introdução das Erínias por Atena no tribunal humano constitui um ato de historização. Com seu ato, Atena permite a comemoração do crime ancestral ea inversão de sua perpetuação apolítica na possibilidade de sua afiliação à íntima monstruosidade consubstancial humana. Assim, essa transposição dos monstros míticos petrificantes no coração da cidade implica, ao mesmo tempo, a historização deles, em sua politização e afiliação na cidade.

As Erínias não são mais a outra face mortificadora do herói; elas param de ser monstros horrendos que petrificam os mortais de temor. A introdução delas na cidade democrática, sua politização e transformação em figuras potencialmente benevolentes é o efeito de sua afiliação à lei da cidade e à palavra dos cidadãos livres.

Enfim, a transformação do monstro havia ocorrido no mito e mais precisamentenomito dePerseue daMedusa. Noentanto, a mudança denomedas Erínias esuanovadenominaçãocomoEumênidesnoespaçotrágicoéumatransformação política e não mítica. Não se trata mais do espelho de Perseu como dispositivo contra o temor e a petrificação mortificadora do olhar da Medusa, mas da força de uma fala da palavra trágica. A nova denominação, esse dizer novo no centro do Aerópago, se dá ao longo do trabalho poético da palavra e constitui a aposta na afiliação de um ódio terrível mas não indizível no mais íntimo do humano.

Recebido/Received: 1/5/2015. Aprovado/Accepted: 7/8/2015

\section{REFERÊNCIAS}

ESCHYLE. (2002) Les Euménides. Paris: Les Belles Lettres. HOMERE. (1973) Odyssée. Trad. de Jean Bérard. Paris: Gallimard. HASSOUN, J. (1998) L'Obscur Objet de la haine. Paris: Aubier. FREUD, S. (1915) Nous juifs et la mort. Die Zeit, n.30, 20 juillet 1990. ROMILLY, J. (1992) Pourquoi la Grèce. Paris: Fallois. MEIER, C. (1980) La Naissance du politique. Paris: Gallimard. PLUTARQUE. (2012) Vies « Périclès » VII. 5 ed. Paris: Les Belles Lettres. DIDIER-WEILL, A. (2010) Un mystère plus lointain que l'inconscient. Paris: Flammarion/Aubier.

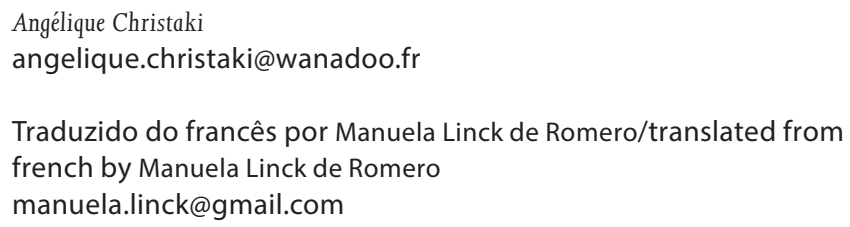

